https://doi.org/10.36909/jer.v9iICRIE.11679

\title{
Assessment age of air and thermal comfort in a classroom by adopting displacement ventilation with chilled ceiling system
}

\author{
Ali Aedan Shbeeb*, Ala'a Abbas Mahdi, and Ahmed Kadhim Hussein \\ College of Engineering, University of Babylon, Iraq \\ *Email: aliaedan@yahoo.com Corresponding Author.
}

\begin{abstract}
This study aims to investigate the effect of the cooling load ratio covered by the chilled ceiling on the age of air and comfort level in a classroom in a hot and dry climate in Iraq-Hilla city. Air age, air exchange efficiency, and concentrations of pollutants in a classroom are investigated numerically by used AIRPAK software under displacement ventilation combined with a chilled ceiling system. Four cases are studied at different values of the cooling load covered by the chilled ceiling $(0 \%, 25 \%, 50 \%, 80 \%)$ with respect to total classroom cooling load. Cooling load removes by chilled ceiling varied from $\left(0\right.$ to $\left.84.5 \mathrm{~W} / \mathrm{m}^{2}\right)$ based on the classroom area, and its temperature varied between $\left(17.5-22.5^{\circ} \mathrm{C}\right)$. The displacement ventilation airflow rate was kept at $0.3 \mathrm{~m}^{3} / \mathrm{s}$, and the air temperature supply varied between $\left(19.5-24.5^{\circ} \mathrm{C}\right)$ depend on the amount of cooling load covered by displacement ventilation. The results showed that the mean local air age increasing with height. The room mean air age increase and air exchange efficiency reduce with increasing load portion, which treated by the chilled ceiling. Increasing the portion of the load treated by chilled ceiling tends to improve comfort levels.

Keywords: chilled ceiling; age of air; displacement ventilation; air-exchange efficiency; CFD.
\end{abstract}




\section{INTRODUCTION}

As epidemics and viruses spread across the world, there is an increasing need to study new approaches to ventilate indoor spaces. Previous studies had shown that displacement ventilation with chilled ceiling has more saving energy and good thermal comfort. Few studies dealt with the study of classroom ventilation, although some studies proved that $50 \%$ of school students suffer from asthma and allergies as a result of air pollution (Karimipanah et al. 2005). (Karimipanah et al. 2005) investigated classroom ventilation by used a jets ventilation system at different thermal conditions by compared experimental and numerical results; the study proved that the CFD program gave very promising results. (Shaughnessy,2015) studied the effects of temperature distribution and ventilation rate on students in the classroom in the Southwestern United States and found that the increase in ventilation rate per second per person leads to improved thermal comfort.

The displacement ventilation system with chilled ceiling was a system that has gained wide popularity in the past few years, is a system characterized by energy-saving and thermal comfort. One of the advantages of the system is that it combines the energy efficiency of displacement ventilation and the efficiency of the chilled ceiling with the possibility of an increase in ventilation performance due to the thermally stratified layers of displacement ventilation systems. (Chakroun et. al. 2011) investigated the saving energy depending on the rate of return air mixed with new fresh air supplied into the room by used (CC/DV) chilled ceiling with the displacement ventilation system, the study found that the mixing fraction up to $60 \%$ improved energy consumption by $37 \%$ when compared with supply total fresh air. (Yang. et. al., 2017) presented numerical study for flow and temperature fields in a room with a combined system (CC/DV); the results showed the position of the radiant cooling surface at the upper zone of the room was given better thermal comfort. (Tian. et al. 2019) studied numerically the variation of 
temperature, humidity and condensation phenomena on the chilled ceiling in the office room with DV system, and the results found that dew condensation on the chilled ceiling could be alleviated by running the DV system for 300s before running chilled ceiling. (Jin et al. 2020) investigated the condensation problem on the chilled ceiling by the change of chilled ceiling surface temperature, found that the flow rate regulation was not effective to prevent the condensation on the surface of the chilled ceiling.

Knowing the age of air inside a closed room can provide us with many data, for example, evaluating air quality in an indoor environment and assessing air pollution control (Awbi. 2017). The combined ventilation system is not used in Iraqi buildings yet; then, it's a good starting point for study the performance of this system in the Iraq-Hilla city climate (hot and dry climate). The study aims to examine the effect of the cooling load ratio treated by the chilled ceiling with respect to total classroom cooling load at constant air flowrate $\left(0.3 \mathrm{~m}^{3} / \mathrm{s}\right)$ on the age of air under hot and dry climate in Iraq-Hila city. The study focused also on the effects of the relation between mean local age of air and temperature on thermal occupants' comfort and performance of students that need a good environment. So in this paper, some questions will be answered such as what's effect of the chilled ceiling on the air exchange efficiency and the effects of the amount of load treated by the chilled ceiling on the thermal comfort in a classroom under hot and dry climate.

\section{CASES DESCRIPTION}

Four cases are studied for the classroom to investigate the effect of the chilled ceiling with displacement ventilation on the indoor age of air and satisfy comfort level under the Iraqi climate in a classroom under the different values of eta $(\eta)$ as shown in the following equation:

$$
\eta=\frac{\mathrm{CL}_{\mathrm{cc}}}{\mathrm{CL}_{\mathrm{DV}}+\mathrm{CL}_{\mathrm{cc}}}
$$

Where $(\eta)$ represented the ratio of the cooling load, which is treated by the chilled ceiling $\left(\mathrm{CL}_{\mathrm{CC}}\right)$ to the total classroom load, and $\left(\mathrm{CL}_{\mathrm{DV}}\right)$ is the load covered by displacement ventilation. 
The $(\eta)$ value change by $0-80 \%$ as $(0,25,50$, and $80 \%)$, when $\eta=0$ that means the cooling load treated by used displacement ventilation only.

The age of air, temperature distribution, and concentration of carbon dioxide $\left(\mathrm{CO}_{2}\right)$ is predicted in a classroom with dimensions of $(9 \times 5 \mathrm{~m}$, and $2.5 \mathrm{~m}$ height $)$, as shown in Figure 1 . The heat load summary of the equipment and occupants in the classroom is shown in table 1. Assuming that the wall with three windows at the south side is exposed to outside conditions (at a maximum temperature in Hilla city summer $47^{\circ} \mathrm{C}$, and $30 \%$ relative humidity). North wall with door oriented to an inside corridor. Other walls are partitions between rooms that have the same design indoor temperature for the classroom $\left(25^{\circ} \mathrm{C}\right)$. The chilled ceiling cover $80 \%$ of the ceiling area divided into three parts, as shown in Figure 1.

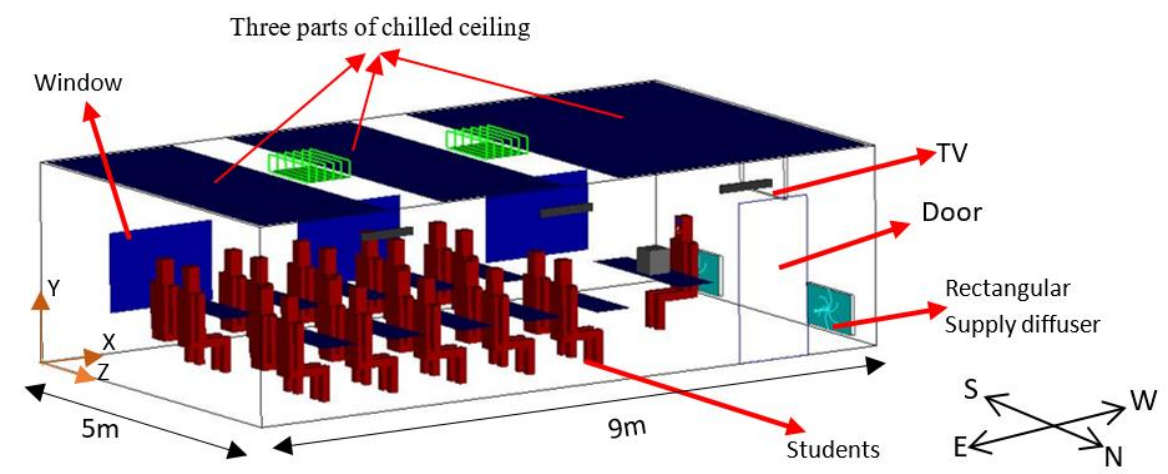

Figure 1 Schematic diagram for the tested room

Table 1 Occupants and equipment heat summary.

\begin{tabular}{|c|c|c|c|}
\hline Items & No. & Power $(\mathrm{W})$ & Power $(\mathrm{W} / \mathrm{m} 2)$ \\
\hline Person & 21 & 75 W per person & 35 \\
\hline Lights & 6 & 480 & 10.66 \\
\hline T.V & 1 & 150 & 3.33 \\
\hline Personal Computer & 1 & 60 & 1.33 \\
\hline
\end{tabular}

\section{SIDEWALL DESCRIPTION}

The walls in most Iraqi buildings were mainly formed of multiple different materials. The thickness of the wall is $30 \mathrm{~cm}$ thickness, and consists of four layers from inside to outside (gypsum plaster $2 \mathrm{~cm}$, cement plaster $2 \mathrm{~cm}$, common Brick $24 \mathrm{~cm}$, cement plaster $2 \mathrm{~cm}$. 


\section{THEORETICAL ANALYSES}

Cooling loads should be calculated by using the method outlined in (ASHRAE handbook. 2013).

By using the following equations:

$$
\begin{aligned}
& \mathrm{Q}=\mathrm{U} \times \mathrm{A} \times \mathrm{CLTD}_{\mathrm{C}} \\
& \mathrm{U}=\frac{1}{\mathrm{R}_{\mathrm{th}}}
\end{aligned}
$$

where $\left(R_{t h}\right)$ is thermal resistance for wall and CLTDc is cooling load temperature different calculated as:

$$
\mathrm{CLTD}_{\mathrm{C}}=(\mathrm{CLTD}+\mathrm{LM}) \times \mathrm{K}+\left(25.5-\mathrm{T}_{\mathrm{i}}\right)+\left(\mathrm{T}_{\mathrm{m}}-29.4\right)
$$

Heat gain by radiation transfer through windows $\left(\mathrm{Q}_{\mathrm{r}}\right)$ is obtained as follows:

$$
\mathrm{Q}_{\mathrm{r}}=\mathrm{A} \times \mathrm{SC} \times \mathrm{SHG} \times \mathrm{CLF}
$$

Where $(\mathrm{LM})$ is the corrector latitude and month, $(\mathrm{K})$ is a color factor, $\left(\mathrm{T}_{\mathrm{m}}\right)$ is mean temperature, (SC) shadow coefficient, (SHG) solar heat gain, and (CLF) is cooling load factor. The heat gain from each side wall, windows, and door of the tested classroom is shown in table 2.

Table 2 Heat gain for the side wall, windows and door

\begin{tabular}{|l|c|c|c|c|c|c|c|c|}
\hline \multirow{2}{*}{ Surface } & \multirow{2}{*}{ West } & \multirow{2}{*}{ East } & \multirow{2}{*}{ North } & \multirow{2}{*}{ south } & \multirow{2}{*}{ Ceiling } & \multicolumn{2}{|c|}{ Window } & \multirow{2}{*}{ Door } \\
\cline { 1 - 3 } & & & & & & Conduction & Radiation & \\
\hline Heat, W & 0 & 0 & 390 & 338 & 0 & 410 & 338 & 67 \\
\hline
\end{tabular}

\section{AIR FLOWRATE AND SUPPLY AIR TEMPERATURE}

To design, and operation of displacement ventilation systems, the method developed by (Chen, and Glicksma. 2003) was the most usually references used. The air flowrate and temperature for supply air $\left(\mathrm{T}_{\mathrm{s}}\right)$ are calculated by the following equations.

$$
\begin{aligned}
& \mathrm{Q}_{\mathrm{DV}}=\frac{0.295 \mathrm{q}_{\mathrm{oe}}+0.132 \mathrm{q}_{1}+0.185 \mathrm{q}_{\mathrm{ex}}}{\rho \mathrm{C}_{\mathrm{p}} \Delta \mathrm{T}_{\mathrm{hf}}} \\
& \mathrm{T}_{\mathrm{s}}=\mathrm{T}_{\mathrm{dr}}-\Delta \mathrm{T}_{\mathrm{hf}}-\frac{\mathrm{A}_{\mathrm{f}} \mathrm{CL}_{\mathrm{DV}}}{0.584 \mathrm{Q}_{\mathrm{DV}}^{2}+1.2 \mathrm{~A}_{\mathrm{f}} \mathrm{Q}_{\mathrm{DV}}} \\
& \mathrm{CL}_{\mathrm{DV}}=\rho \mathrm{Q}_{\mathrm{DV}} \mathrm{C}_{\mathrm{p}}\left(\mathrm{T}_{\mathrm{e}}-\mathrm{T}_{\mathrm{s}}\right)
\end{aligned}
$$

Where ( $\mathrm{q}_{\mathrm{oe}}, \mathrm{q}_{1}$, and $\mathrm{q}_{\mathrm{ex}}$ ) are the heat gain by occupants, light, and external respectively, ( $\left.\mathrm{Q}_{\mathrm{DV}}\right)$ is the airflow rate, and $\left(\Delta \mathrm{T}_{\mathrm{hf}}\right)$ is the temperature difference between head and foot.

The supply flow rate $\left(\mathrm{Q}_{\mathrm{DV}}\right)$ is fixed at $(300 \mathrm{~L} / \mathrm{s})$ for each test and the diffuser supply air temperature $\left(\mathrm{T}_{\mathrm{s}}\right)$ varied depending on the value of cooling load covered by use displacement 
ventilation $\left(\mathrm{CL}_{\mathrm{DV}}\right)$ at constant air flowrate. The indoor air conditions for classroom design as dry bulb temperature $\left(\mathrm{T}_{\mathrm{rd}}\right)$ of $\left(25^{\circ} \mathrm{C}\right.$ due to ASHRAE standard 2007). The initial value of $\mathrm{CO}_{2}$ concentration inside the test room is $(1000 \mathrm{ppm})$ to estimate the required time to reach the $\mathrm{CO}_{2}$ concentration in supply air (400ppm) for each case.

To calculate the temperature of the chilled ceiling surface $\left(\mathrm{T}_{\mathrm{CC}}\right)$, the following empirical equation is used (Hao, X. et. al. 2007).

$\mathrm{T}_{\mathrm{CC}}=\mathrm{T}_{\mathrm{dr}}\left(\frac{\mathrm{CL}_{\mathrm{CC}}}{8.92 \cdot f \cdot \mathrm{A}_{\mathrm{f}}}\right)^{0.9}$

Wher $\left(\mathrm{T}_{\mathrm{dr}}\right)$ is the design room temperature and $(f)$ is the ratio of chilled ceiling area $\left(\mathrm{A}_{\mathrm{cc}}\right)$ to the floor area $\left(\mathrm{A}_{\mathrm{f}}\right)$.

Table 3 shows the values of calculated air supply temperature $\left(\mathrm{T}_{\mathrm{s}}\right)$, and chilled ceiling surface temperature $\left(\mathrm{T}_{\mathrm{CC}}\right)$ at a different ratio of cooling load $(\eta)$ for four cases.

Table 3 Operating conditions for cases

\begin{tabular}{|l|l|l|l|l|l|l|l|l|}
\hline \multicolumn{1}{|c|}{ Cases } & $\boldsymbol{\eta} \mathbf{\%}$ & $\begin{array}{c}\mathbf{C L}_{\mathbf{D V}} \\
(\mathbf{W})\end{array}$ & $\begin{array}{c}\mathbf{C L}_{\mathbf{C C}}, \\
(\mathbf{W})\end{array}$ & $\begin{array}{c}\mathbf{Q}_{\mathbf{D V}}, \\
\left(\mathbf{m}^{\mathbf{3}} / \mathbf{s}\right)\end{array}$ & $\begin{array}{c}\mathbf{T}_{\text {amp, }} \\
\left({ }^{\circ} \mathbf{C}\right)\end{array}$ & $\begin{array}{c}\mathbf{T}_{\mathbf{s}} \\
\left({ }^{\circ} \mathbf{C}\right)\end{array}$ & $\begin{array}{c}\mathbf{R H}_{\mathbf{s}} \\
\mathbf{\%}^{\circ}\end{array}$ & $\begin{array}{c}\mathbf{T}_{\mathbf{c c}} \\
\left({ }^{\circ} \mathbf{C}\right)\end{array}$ \\
\hline Case-1 & 0 & 3808 & 0 & 0.3 & 47 & 19.5 & 70 & - \\
\hline Case-2 & 25 & 2856 & 952 & 0.3 & 47 & 21.5 & 65 & 22 \\
\hline Case-3 & 50 & 1904 & 1904 & 0.3 & 47 & 23.5 & 60 & 20 \\
\hline Case-4 & 80 & 761.6 & 3046.4 & 0.3 & 47 & 24.5 & 55 & 17.5 \\
\hline
\end{tabular}

SELECTION OF AIR SUPPLY DIFFUSER

Depending on the value of air flowrate $\left(0.3 \mathrm{~m}^{3} / \mathrm{s}\right)$, and to satisfy low air velocity $(0.3 \mathrm{~m} / \mathrm{s})$, two on way rectangular diffusers with the area $\left(0.5 \mathrm{~m}^{2}\right)$ as shown in Figure 2 are selected to delivers cooled air. The surrounding classrooms are typically arranged with the teacher's desk at one side of the room, and students sit in rows facing the teacher. The most common diffuser arrangement for this room layout requires spreading on each side of the wall near a teacher. 


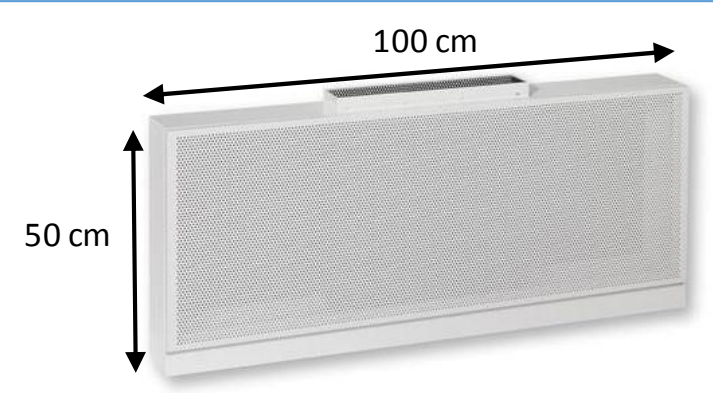

Figure 2 One way rectangular diffuser

\section{GOVERNING EQUATIONS}

The Reynolds Averaged Navier_Stokes equations are covered the continuity equation, energy equation and momentum equation as follows (Pijush and David 2012):

1- Continuity equation

$$
\frac{\partial}{\partial x}(u)+\frac{\partial}{\partial x}(v)+\frac{\partial}{\partial x}(w)=0
$$

2- Conservation of momentum

$$
\begin{aligned}
& \frac{\partial}{\partial x}(\rho u u)+\frac{\partial}{\partial y}(\rho u v)+\frac{\partial}{\partial z}(\rho u w)=-\frac{\partial p}{\partial x}+\frac{\partial}{\partial x}\left(u \frac{\partial u}{\partial x}\right)+\frac{\partial}{\partial y}\left(u \frac{\partial u}{\partial y}\right)+\frac{\partial}{\partial z}\left(u \frac{\partial u}{\partial z}\right) \\
& +\frac{\partial}{\partial x}\left(-\rho u^{\prime} u^{\prime}\right)+\frac{\partial}{\partial y}\left(-\rho u^{\prime} v^{\prime}\right)+\frac{\partial}{\partial z}\left(-\rho u^{\prime} w^{\prime}\right)+\rho g_{x}
\end{aligned}
$$

3. Energy equation

$$
\frac{\partial}{\partial x}(\rho U T)+\frac{\partial}{\partial y}(\rho \mathrm{VT})+\frac{\partial}{\partial z}(\rho \mathrm{WT})=\frac{\partial}{\partial x}\left(\Gamma \frac{\partial T}{\partial x}\right)+\frac{\partial}{\partial y}\left(\Gamma \frac{\partial T}{\partial y}\right)+\frac{\partial}{\partial z}\left(\Gamma \frac{\partial T}{\partial z}\right)
$$

\section{TURBULENCE MODEL AND MESH STRATEGY}

The commercial CFD software used in this work is (AIRPAK.3.0.16). Many researchers in a field DV/CC system have used (AIRPAK) software in the numerical analysis as (Gao S. et. al. 2017), (Yang. et. al. 2017), and (Ayoub. et. al. 2006).

To ensure the accuracy of the results of the AIRPAK software to work in the field of DV/CC system, it was validated with another experimental study. Validation was achieved by comparing the numerical results done by software, and experimental data obtained from the office room with DV/CC system conducted by (Rees. 1998). The comparison by used AIRPAK software 
(RNG k- $\varepsilon$ turbulent model) gave a good agreement between experimental simulated results ((Rees. 1998) at average error was about 3.27\%.

Renormalization Group Method (RNG k- $\varepsilon$ ) was a good choice as a turbulent model for used in numerical analysis for this study (Chen, Q. 1995).

For modeling the flow by using the AIRPAK software, it is necessary to divide the room geometry into cells that include a mesh. Acceptable mesh strategy depending on compared among six mesh strategy (962531, 1133262, 1214510, 1351966, 1564681, and 1806426 Nodes).

Five positions were chosen to acquire the age of air results: $\mathrm{P}_{1}(6,0.4,4), \mathrm{P}_{2}(7,1.8,2.5), \mathrm{P}_{3}$ $(2,1.1,2.5), \mathrm{P}_{4}(3,1.8,3.5)$, and $\mathrm{P}_{5}(4,1.1,2.5)$. Figures 3-a, and 3-b show air age, and temperature profiles respectively for six different nodes number.

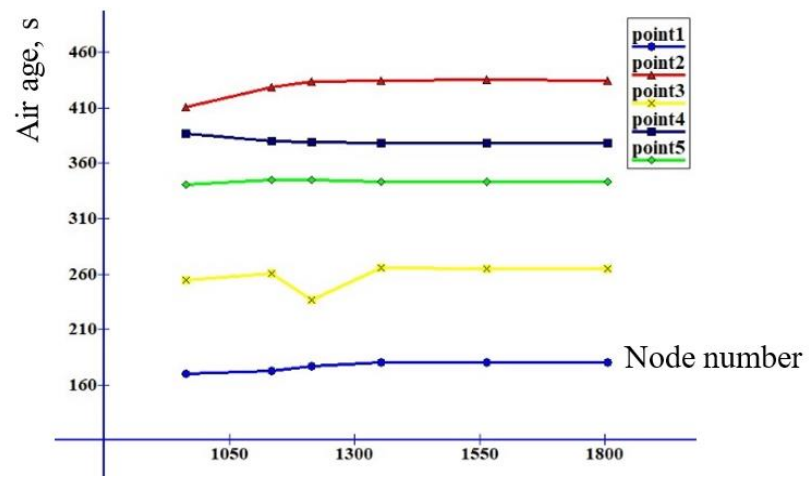

a- Air age profile

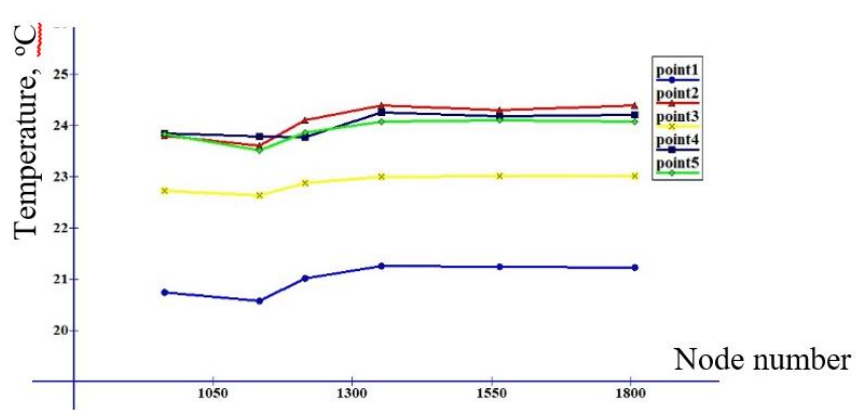

b- Temperature profile

Figure 3 Air age and temperature profiles for six different node numbers per thousand After applying the above mesh strategy, the acceptable element number and nodes for the model study by AIRPAK are (1351966 nodes) for the case without (CC) and (1380951) for cases with (CC). Figure 4 shows parts of the meshed model. 


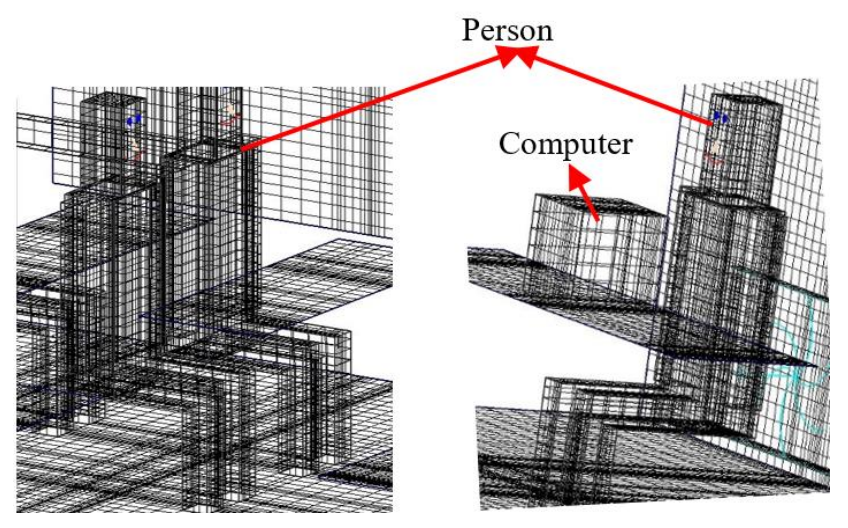

Figure 4 part from meshed model

\section{PREDICT INDOOR AIR QUALITY PARAMETERS IAQ}

After complete cases analyses by Airpak software, the indoor air quality (IAQ) parameters can be predicted such as mean age of air $(\tau)$, air exchange efficiency $\left(\eta_{a}\right)$, temperature effectiveness $\left(\varepsilon_{\mathrm{t}}\right)$, predicted mean vote (PMV), and predicted percentage dissatisfied (PPD) as shown in the following equations: (Awbi, 2008, Gao. et al. 2017 and ASHRAE 2013)

$$
\begin{aligned}
& \tau_{\mathrm{n}}=\frac{\mathrm{V}}{\mathrm{Q}_{\mathrm{DV}}} \\
& \eta_{a}=\frac{\tau_{n}}{2\langle\tau\rangle} \\
& \varepsilon_{t}=\frac{T_{e}-T_{s}}{T_{a v}-T_{s}} \\
& \mathrm{PMV}=[0.303 \exp -[0.036 \mathrm{M}+0.02] \mathrm{L} \\
& \mathrm{PPD}=100-\exp -\left[0.03353(\mathrm{PMV})^{4}+0.2179(\mathrm{PMV})^{2}\right]
\end{aligned}
$$

\section{RESULTS AND DISCUSSION}

DV/CC system was studied numerically in a classroom under Iraqi- Hilla city climate at maximum summer temperature. The study is identified based on the different cooling load chilled ceiling ratio $(\eta)$. The main results parameters obtained in the numerical analyses by ARIPAK software are summarized in table 4. 
Table 4 Numerical parameters for four cases

\begin{tabular}{|l|c|c|c|c|c|c|c|c|c|c|}
\hline Cases & $\eta \%$ & $\begin{array}{l}\mathrm{Q}_{\mathrm{DV}} \\
\left(\mathrm{m}^{3} / \mathrm{s}\right)\end{array}$ & $\mathrm{T}_{\mathrm{s}}{ }^{\circ} \mathrm{C}$ & $\begin{array}{l}\mathrm{T}_{\mathrm{CC}} \\
\left({ }^{\circ} \mathrm{C}\right)\end{array}$ & ADPI \% & PMV & PPD\% & $\begin{array}{l}\Delta \mathrm{T}_{\mathrm{hf}} \\
\left({ }^{\circ} \mathrm{C}\right)\end{array}$ & $\eta_{\mathrm{a}} \%$ & $\varepsilon_{t}$ \\
\hline Case-1 & 0 & 0.3 & 19.5 & - & 50.14 & 0.815 & 19.5 & 2.2 & 72.8 & 1.38 \\
\hline Case-2 & 25 & 0.3 & 21.5 & 22 & 50.17 & 0.783 & 19.1 & 1.4 & 70.7 & 1.31 \\
\hline Case-3 & 50 & 0.3 & 23.5 & 20 & 58.97 & 0.765 & 18.7 & 0.9 & 69.93 & 1.28 \\
\hline Case-4 & 80 & 0.3 & 24.5 & 17.5 & 81.54 & 0.69 & 17 & 0.4 & 57.2 & 1.25 \\
\hline
\end{tabular}

The vertical mean age of air profiles in a classroom for the four cases is shown in Figure 5. Notes that the mean air age increase with increase portion of cooling load treated by the chilled ceiling, although the airflow was constant. That clearly at the level above (1m) especially at $\eta$ equal ( 25 , and $50 \%)$. That's leading to a decrease in the air exchange efficiency $\left(\eta_{\mathrm{a}}\right)$ with increase value of ( ) as shown in Figure 6. This result explains the effect of cooled air, which moves down due to convection from the chilled ceiling, and its disruption of hot rising air, which reduces the airspeed in general. Reduces in air exchange efficiency $\left(\eta_{a}\right)$ means increase in time required for fresh air to replace the old air in a classroom zone, which affects student performance.
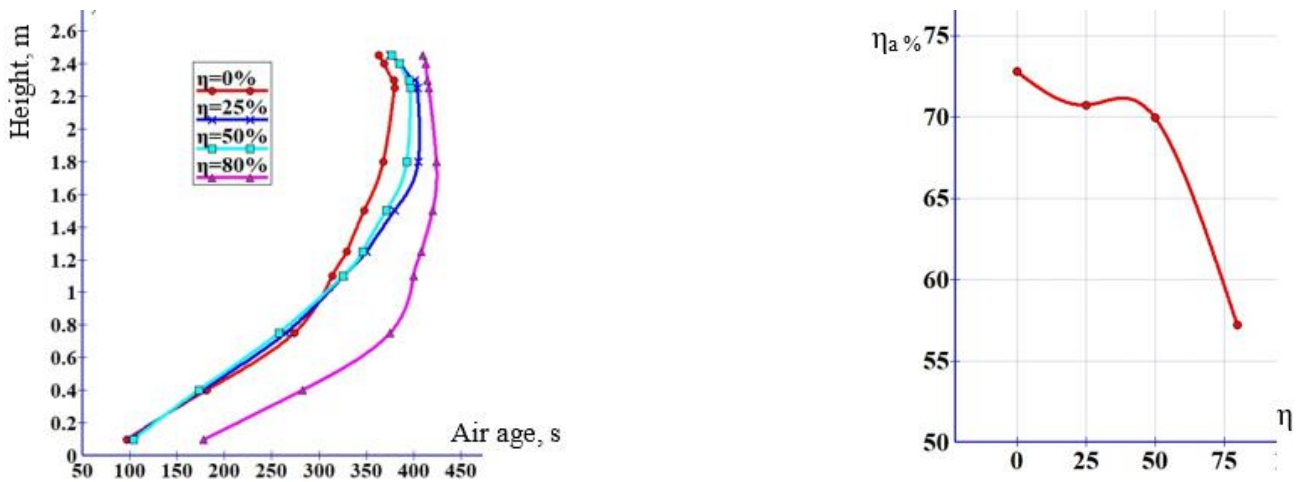

Figure 5 Mean air age profiles with height Figure 6 Air exchange efficiency at different $(\eta)$

Figures 7, and 8 show the profiles of PMV, and PPD for four cases, notes that the PMV, and PPD values are improving with the increase value of $\eta$, and more converge to the values, which specified by ASHRAE standard $2013(-0.5 \leq \mathrm{PMV} \leq 0.5$, and $\mathrm{PPD}=10 \%$,$) . At a value of ( \eta)$ increase from $(0 \%, 25 \%, 50 \%$ to $80 \%)$ the PMV decrease from $(0.815,0.783,0.765$, and 0.69$)$ 
respectively that's mean the increase in the portion of load treated by chilled ceiling lead to improve thermal comfort.

Figure 9 shows the relation between ADPI and $\eta$, notes that the ADPI increases with increase $\eta$, it reaches to $81 \%$ at $\eta$ equal to $80 \%$ and converges from the design goal specified by (ASHRAE Fundamentals, 2001). That means the increase in value of $(\eta)$ gives a more acceptable comfort level.

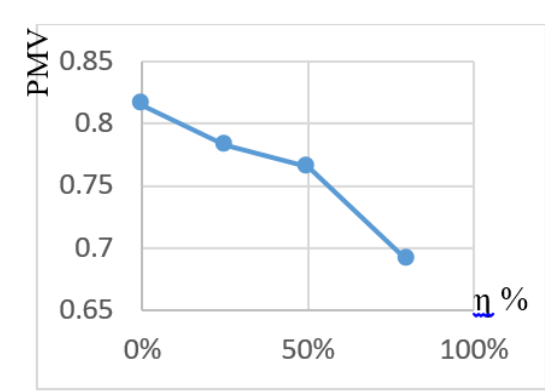

Figure 7 PMV profile at different $(\eta)$

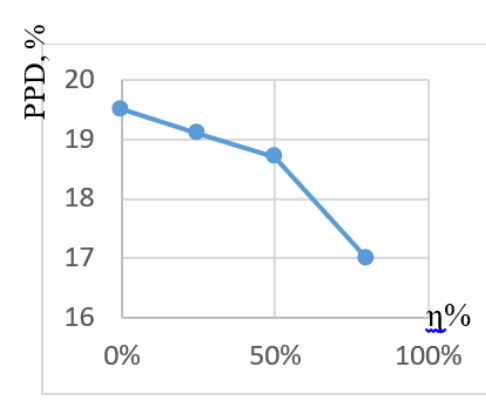

Figure 8 PPD profile at different $(\eta)$

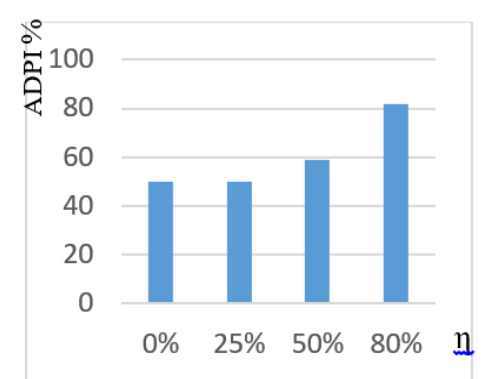

Figure 9 ADPI profile at different $(\eta)$

Temperature gradient with height is one of the properties that differentiate the displacement ventilation system. Figure 10 show effect of chilled ceiling on the temperature distribution with height at different value of $(\eta)$. The temperature stratification decrease s with increase $(\eta)$ due to the effect of the low temperature of the chilled ceiling and therefore decrease in air temperature at the upper zone and it falls. This means that the increase in $(\eta)$ value tends to decrease thermal efficiency by 0.13 between $0-80 \%$ values of $\eta$ at constant supply air flow as shown in Figure 11 due to decrease in the exhaust air temperature. (ASHRAE Standard, 1984) found that the value of temperature difference between foot and head of a seated about $2^{\circ} \mathrm{C}$. As shown in Figure.12, the decrease in temperature gradient with $(\eta)$ leads to decrease in temperature difference between head and foot of a seated by $1.8^{\circ} \mathrm{C}$ between $0-80 \%$ values of $\eta$. 


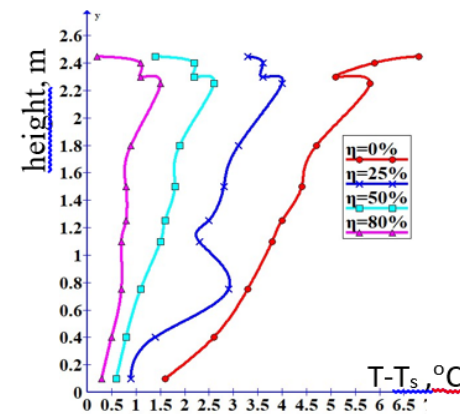

Figure 10 Temperature gradient with height

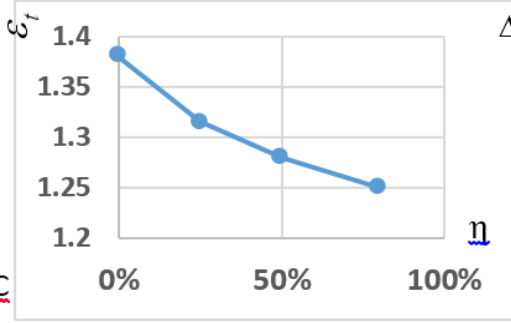

Figure 11 Thermal efficiency at different $(\eta)$

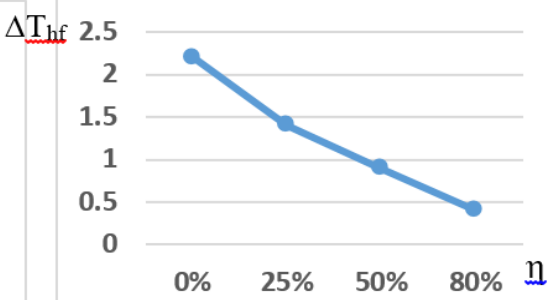

Figure $12 \Delta \mathrm{T}_{\mathrm{hf}}$ at different

$(\eta)$

Figure 13a-d shows the indoor removal speed of carbon dioxide and the time required for carbon dioxide concentration to reach $400 \mathrm{ppm}$ (According to ASHRAE Standard 62) starting from $1000 \mathrm{ppm}$ for each case at different $(\eta)$. The results show that the increased load treated by chilled ceiling at constant air supply flowrate ( $\left.Q_{D V}\right)$ has a slight effect on the carbon dioxide removing speed. The carbon dioxide concentration takes time about (1200s) to reach the supply concentration value $(400 \mathrm{ppm})$ for four cases at different $(\eta)$. This result means that the carbon dioxide removing speed depends on the amount of air flowrate supplied to the classroom, despite the temperature change.

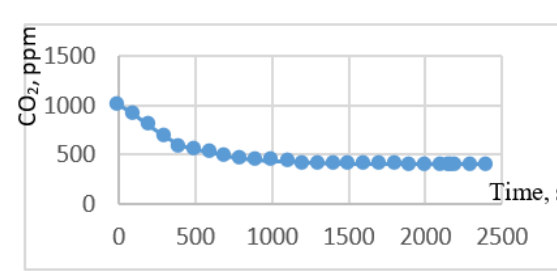

a- $\eta=0 \%$

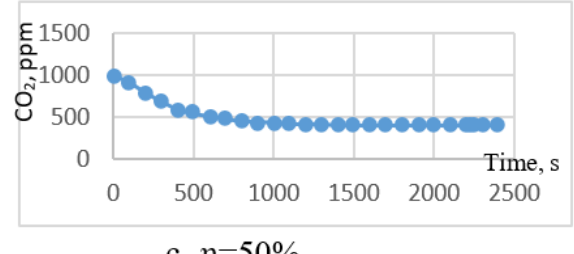

c- $\eta=50 \%$

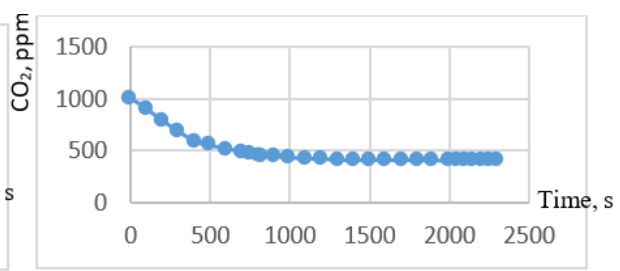

$b-\eta=25 \%$

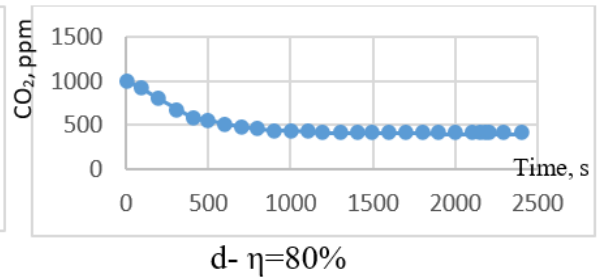

Figure 13 Time required for remove carbon dioxide at different $\eta$

Figure $14 \mathrm{a}-\mathrm{d}$ shows the mean air age distribution contours of the classroom for four cases at $\mathrm{z}=1.1 \mathrm{~m}$. The age of air starts from zero at the air supply diffuser and increases in the indoor zone. The age of air increase with room height and notes the maximum values of air age at zone up to 
diffuser location in four cases, that's mean low air movement in this zone lead to increase in pollution concentration and occupants discomfort in this zone. Increase value of $(\eta)$ leads to increase in the value of the age of air due to interchange the cool air coming from the cooling ceiling and the hot air rise. Notes that the increase in air temperature near the human body by convection leads to decrease in the age of air in this zone due to increasing air velocity around the human body because of rising its temperature.

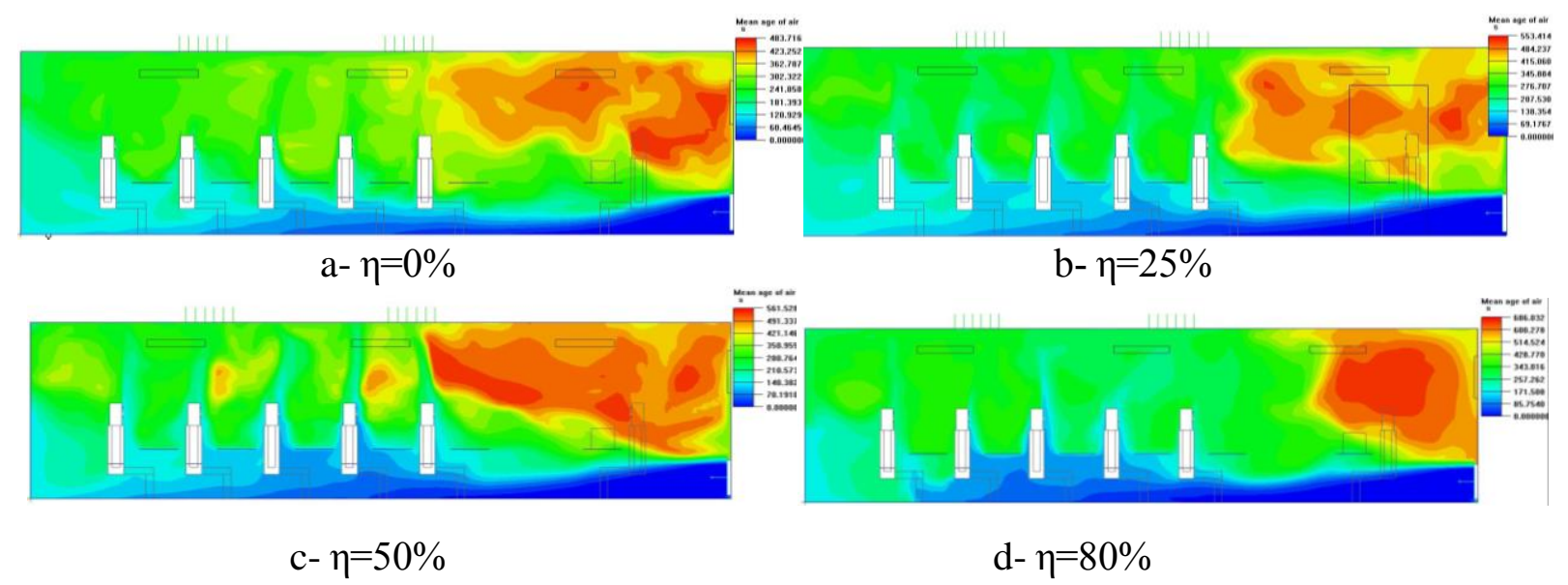

Figure 14 Age of air contours at different $(\eta)$ for four cases $z=1.1 \mathrm{~m}$

\section{CONCLUSIONS}

The feasibility of displacement ventilation combined with the chilled ceiling has been studied numerically by used ARIPAK software under the Iraqi-Hilla city climate (hot and dry climate). The strategy of study is based on changing the cooling load amount, which treated by used chilled ceil with respect to classroom cooling load at constant air flowrate by displacement ventilation. The mean age of air and thermal comfort of the DV/CC system is investigated numerically. Effect the relation between the mean local air age and temperature on comfort level are analyzed. The main conclusions are found as follows:

1- The mean local air age increases with height and then begins to decrease at air closer to the ceiling. The mean air age increase with increase in the portion of cooling load treated by chilled ceil lead to reduce air exchange efficiency

2- (PMV), and (PPD) is improving with an increasing portion of cooling load treated by chilled ceil tend to increase in ADPI value. 
3- The mean local air age increase with increase in the air temperature around the heat source.

4- Carbon dioxide removing speed, not effects with increase the supply temperature, and the portion of load treated by chilled ceil at a constant airflow rate.

5- The temperature difference between head and foot was reduced with an increase in heat remove by the chilled ceiling, and the temperature stratified being unclear.

Airpak 3.0 User's Guide. 2007.

\section{REFERENCES}

ASHRAE Fundamentals Handbook. 2013.

ASHRAE handbook. 2012. Heating, HVAC Systems and Equipment (SI). Panel heating and cooling.

Awbi, H. B. 2008. Ventilation of buildings. Taylor \& Francis. Second edition.

Awbi, H. B. 2017. Ventilation for good indoor air quality and energy efficiency. Energy Procedia, 112: 277-286. https://doi.org/10.1016/j.egypro.2017.03.1098

Ayoub, M., Ghaddar, N., \& Ghali, K. 2006. Simplified thermal model of spaces cooled with combined positive displacement ventilation and chilled ceiling system. HVAC\&R Research, 12(4): 1005-1030. DOI: 10.1080/10789669.2006.10391448

Cao, G., Awbi, H., Yao, R., Fan, Y., Sirén, K. and Kosonen, R. 2014. A review of performance of different ventilation and airflow distribution systems in build. Building and Environment, 73: 171-186. https://doi.org/10.1016/j.buildenv.2013.12.009

Chakroun, W., Ghaddar, N., \& Ghali, K. 2011. Chilled ceiling and displacement ventilation aided with personalized evaporative cooler. Energy and buildings, 43(11): 3250-3257. https://doi.org/10.1016/j.enbuild.2011.08.026

Chen, Q. 1995. Comparison of different $k-\varepsilon$ models for indoor air flow computations. Numerical Heat Transfer, Part B Fundamentals, 28(3): 353-369.

Chen, Q., \& Glicksman, L. 2003. System performance evaluation and design guidelines for displacement ventilation:[prepared under ASHRAE research project 949]. American Society of Heating, Refrigerating, and Air-Conditioning Engineers. https://doi.org/10.1016/j.applthermaleng.2019.114827.

Gao, S., Wang, Y. A., Zhang, S. M., Zhao, M., Meng, X. Z., Zhang, L. Y. \& Jin, L. W. 2017. Numerical investigation on the relationship between human thermal comfort and thermal balance under radiant cooling system. Energy Procedia, 105: 2879-2884. https://doi.org/10.1016/j.egypro.2017.03.640 
Hao, X., Zhang, G., Chen, Y., Zou, S., \& Moschandreas, D. J. 2007. A combined system of chilled ceiling, displacement ventilation and desiccant dehumidification. Building and Environment, 42(9): 3298-3308. https://doi.org/10.1016/j.buildenv.2006.08.020

Jin, W., Jing, J., Jia, L., \& Wang, Z. 2020. The dynamic effect of supply water flow regulation on surface temperature changes of radiant ceiling panel for cooling operation. Sustainable Cities and Society, 52: 101765.

Karimipanah, T., Awbi, H. B., Blomqvist, C., Sandberg, M., \& Fresh, A. B. 2005. Effectiveness of confluent jets ventilation system for classrooms. In Proceedings of the 10th International Conference in Indoor Air Quality and Climate-Indoor Air (Vol. 5, pp. 3271-3277).

Norbäck D., Wieslander G., Zhang X. \& Zhao Z. 2011. Respiratory symptoms, perceived air quality and physiological signs in elementary school pupils in relation to displacement and mixing ventilation system: an intervention study, Indoor Air 21 (5): 427-437. DOI: 10.1111/j.1600-0668.2011.00717.x

Pijush K, Ira M. \& David R. 2012. Fluid mechanics, Elsevier, fifth edition.

Rees, S. J. (1998). Modelling of displacement ventilation and chilled ceiling systems using nodal models (Doctoral dissertation, (c) Simon John Rees).

Shaughnessy U, Richard J. 2015. Effects of Classroom Ventilation Rate and Temperature on Students. PLoS ONE, 10(8), e0136165.

Tian, Y., Guo, S., Jin, G., Pang, Y., Wang, X., Wu, W., \& Zhao, J. 2019. A two-step approach to solve the issue of dew condensation for displacement ventilation and chilled ceiling system. Energy Procedia, 158: 6527-6531.

https://doi.org/10.1016/j.egypro.2019.01.106

Yang, Y., Wang, Y., Yuan, X., Zhu, Y., \& Zhang, D. 2017. Simulation study on the thermal environment in an office with radiant cooling and displacement ventilation system. Procedia Engineering, 205: 3146-3153. doi.org/10.1016/j.proeng.2017.10.142. 